G.L.A. Harris, Ph.D., Associate Professor, Mark O. Hatfield School of Government, College of Urban and Public Affairs, Portland State University Ayanna Shivers, Human Performance Resource Center, Consortium for Health and Military Performance (CHAMP), Uniformed Services University of the Health Sciences (USUHS)

Patricia Deuster, Ph.D., Director, Consortium for Health and Military Performance (CHAMP), Uniformed Services University of the Health Sciences (USUHS)

\title{
EMPLOYING HUMAN PERFORMANCE OPTIMIZATION INITIATIVES FROM HISTORICALLY BLACK COLLEGES AND UNIVERSITIES: THE CASE OF THE U.S. MILITARY
}

\begin{abstract}
To preemptively respond to the ever changing battlefield and in light of growing threats to national security, the U.S. Department of Defense (DoD) and by extension the U.S. military, have developed human performance optimization (HPO) initiatives to improve warfighter performance for increasing mission readiness. African American officers, by way of the Reserve Officer Training Corps (ROTC) at Historically Black Colleges and Universities (HBCUs), have long been and continue to be an important constituency for this strategy.
\end{abstract}

Using the results of an online search via the Internet of HPO-like academic offerings at HBCUs, this paper proposes that the U.S. military could enhance its war fighting capability, and specifically that of its African American officers, for increased preparedness, increased performance and sustained and increased readiness by modeling HPO like programs at HBCUs. The authors examine similar efforts around the world, offer the potential benefits to be derived from expanded collaborations between the U.S. military and HBCUs and discuss the implications for the U.S. military and militaries within international communities, HBCUs and future research. 


\section{Keywords}

human performance optimization (HPO), warfighter, readiness, Historically Black Colleges and Universities (HBCUs), Reserve Officer Training Corps (ROTC), African Americans, Blacks, U.S. military

\section{Introduction}

The United States (U.S.) military continually strives to improve its warfighter capability. To that end, human performance optimization (HPO) initiatives have become vital in the quest for increasing and sustaining mission readiness. Further, in the new environment with an emphasis on the military services working in tandem as a joint force, and in light of growing threats to national security, HPO initiatives have become all the more important as a strategy for improving and optimizing the human performance capabilities of warfighters for the U.S. military to achieve asymmetric power over its enemies (Brown and Tvyaryanas 2008). One important constituency for meeting this strategy, and to which the military has customarily turned to fulfill its war fighting force, is African Americans. ${ }^{1}$ Historically Black Colleges and Universities (HBCUs) have long been identified as a primary conduit for the recruitment of African Americans to the commissioned corps of the military (Department of Defense (DoD) 1999). Owing to this relationship between the military and the HBCUs, of the existing 105 HBCUs (U.S. Department of the Interior (DOI)), 27 have established Reserve Officer Training Corps (ROTC) programs with the military for the services (Army, Navy, Marines and Air Force) with the Army as the largest beneficiary; the largest number of African American officers emanate from these HBCUs (DoD 1999).

The U.S. military is growing dependent on HBCUs for African Americans in the commissioned corps and its concomitant installation of ROTC programs as a symbol of commitment to better prepare HBCU graduates to join its ranks. Thus, the military may similarly benefit from other programs within HBCUs that may fall outside the purview of already established ROTC programs. These non-military programs may mimic, in one form or another, the components of military HPO initiatives, and are therefore HPO like in character. However, because these non-military HPO initiatives constitute 
academic coursework, they will hereafter be referred to as HPO-like academic offerings ${ }^{2}$. As such, the premise of this paper is to examine the degree to which HPO-like academic offerings are present at HBCUs and how the military could take advantage of this potentially invaluable knowledge base to enhance its warfighter training to increase mission readiness. First, the authors explore HPO initiatives in the U.S. military and whether or not comparable initiatives or academic coursework exist within HBCUs. In doing so, the authors also determine whether or not like initiatives exist in other militaries around the world. Second, we examine the extent to which such initiatives are available and what characteristics of these initiatives could prove complementary to those of the military and if the military can capitalize on these HPO-like academic offerings. Third, we attempt to answer the question: how can the military further leverage the importance and use of HPO-like academic offerings at HBCUs to its benefit? Finally, the authors discuss the implications that HPO-like academic offerings may hold for the U.S. military as well as its international counterparts, HBCUs and the prospects for future research in this arena.

\section{Literature Review}

The U.S. military recognizes that the nature of the modern battlefield has devolved into an unpredictable and dynamic environment. Multiple studies on environmental and situational stressors; sleep deprivation; nutritional supplements and/or pharmaceutical enhancing products; brain plasticity and learning in training; and certain medical interventions, both non invasive and invasive, of civilian populations; have been validated for their effects on human performance with wide ranging applicability and utility for the military (Williams et al. 2008). Similarly, studies on military personnel have borne out like results on the decrement and enhancement of human performance (U.S. Army Research Institute of Environmental Medicine, Institute of Medicine 2004). More importantly, though, the focus has been on how current and potential adversaries of the United States could exploit these same mechanisms through unethical or non medical means (Sarewitz and Karas 2008). Thus, in an effort to anticipate, respond, and adapt to these unforeseen challenges, optimizing human performance has become a central theme for the U.S. Department of Defense (DoD) (Deuster et al. 2007). New research in the aforementioned as tools to gain asymmetric advantage over 
opponents may be needed. At the center of this initiative lies the warfighter as the "ultimate weapon system" (Tvaryanas et al. 2008) or "human weapon system" (Tvaryanas et al. 2009) because "humans are more important than hardware" (Deuster et al. 2007, 1133). This renewed, yet novel, way of viewing the warfighter has been motivated by the increasing demands of the Global War on Terror, which requires the optimal capability and performance of military personnel (Deuster et al. 2007). The relatively recent proliferation of human performance optimization research by the services in the United States directly corresponds with the call for action by DoD to spur research activity in this area.

\section{What are HPO Initiatives?}

Part of the overarching goal of DoD for developing a strategy for human performance optimization includes standardizing how the term is defined and measured and to allow for variances in how HPO initiatives are executed with consideration for service specific requirements. But, defining HPO has been inconsistent since HPO means different things to different people (Brown (Interview) 2010). A panoply of terms used synonymously with human performance optimization has emerged. These terms include human weapon system (Tvaryanas et al. 2009), human performance enhancement (Brown and Tvaryanas 2008), human performance evaluation (Rabbi et al. 2009), and human performance modification (Williams et al. 2008). Although no uniformed definition for human performance optimization per se has been agreed upon (Tvaryanas et al. 2009), and despite the varying use of terms to define the concept, all terms share underlying elements that describe optimizing human performance. Integral to this definition has been how socio-emotional, physical and cognitive variables interact to impact human performance (Consortium for Health and Military Performance (CHAMP) website).

The cornerstone of DoD's strategy for human performance optimization then has been driven by the need for a standardized definition and establish performance indicators for how HPO is measured in accordance with DoD's needs; to institute and streamline the means by which HPO information is both communicated and coordinated across various stakeholders, including the military and those within research, medical and operations; to promote HPO within DoD; and to convert research findings for application in the 
field (Deuster et al. 2007). For force health protection, a system designed as a resource for military personnel to inform on sound and scientifically based evidence for maintaining a healthy lifestyle (Singh et al. 1999), the strategy is to position the United States as the dominant force within the domain (Deuster et al. 2007). To achieve this strategy, a number of objectives for optimizing the performance of the warfighter have been identified, namely, improving mental and physical resilience, lowering the number of injuries and illnesses as well as quickening the recovery time from them, and facilitating the ease of information transmission from research to the field to increase mission readiness.

Taken together, the coordinated push by the services, DoD and the Joint Medical Research Command, has resulted in the operational definition of human performance optimization as the utilization and application of knowledge, skills, abilities and technologies to enhance and sustain the war fighting capabilities of military personnel (CHAMP). Using doctrinal language on force health protection from the Military Health System (MHS) for a healthy and fit force, prevention and protection and medical and rehabilitative care (Tvaryanas et al. 2009), Tvaryanas et al. (2009) offered an alternate three tiered performance based force projection model for achieving human performance optimization. Performance sustainment ensures the readiness of the warfighter by maintaining certain performance levels throughout the person's career; performance optimization ensures the warfighter's efficient use of resources; and performance enhancement challenges the innate performance capabilities of the warfighter to reach new performance thresholds. Hence, HPO initiatives are those tools employed to bring about the optimization of warfighter performance (CHAMP). These tools may include, but are not limited to, the use of nutritional supplements, nutraceuticals or pharmaceuticals (Williams. et al. 2008, CHAMP), techniques or practices (CHAMP), equipment or machines, and through the use of biotechnologies based on genetic data. Whatever the definition, HPO and its ensuing initiatives point to the processes and tools for optimizing the capability and performance of the warfighter to meet mission demands.

\section{What are HBCUs?}

Historically Black Colleges and Universities (HBUCSs) have been described as repositories for Black leadership. The beginnings of these institutions 
some 160 years ago came in response to racial segregation in education in the United States (Collins and Hamaifar 2007). Most HBCUs are 50 years old to 100 years old with the oldest dating back to 1837 (U.S. Department of Institution (DOI)). Many HBCUs have served as proving grounds for some of the most well known African American leaders, most notably Martin Luther King, Jr., Thurgood Marshall, Oprah Winfrey and Julian Earls. These schools were only recognized as legitimate institutions of higher learning by the United States since 1965 with the passing of the Higher Education Act and designated by the U. S. Department of Education as HBCUs with the affording national accreditations. Over time, these institutions have come to represent places of refuge to preserve, cultivate, and nurture the Black culture and experience (Armstrong 2002, Collins and Hamaifar 2007). HBCUs are known to provide an especially nurturing environment that is richly steeped in faculty-student relationships where students are shepherded through experiences not often found at predominantly White institutions (PWIs) (Steinfeldt et al. 2009). It is this special bond that is key to the success of HBCU graduates, particularly once they move on to confront the challenges of the larger American society (Quarterman et al. 1996). HBCUs comprise $3 \%$ of the nation's colleges and universities, currently stand at 105 in total (U.S. Department of the Interior (DOI)) from a height of 117 (DoD 1999) in 1997 and represent $16 \%$ of African Americans who are enrolled in these institutions (U.S. DOI). Thus, HBCUs continue to play a critical role in educating Black youth. Table 1 is a composite of the nations' HBCUs.

Table 1. Composite of Historically Black Colleges and Institutions (HBCUs) in the United States

\begin{tabular}{|c|c|c|}
\hline Type Institution & $\begin{array}{c}\text { No. of Institutions Per } \\
\text { Type }\end{array}$ & $\begin{array}{c}\text { Percent (\%) of Total } \\
\text { HBCUs }\end{array}$ \\
\hline 4-year public & 40 & 38.09 \\
\hline 4-year private & 49 & 46.66 \\
\hline 2-year public & 11 & 10.48 \\
\hline 2-year private & 5 & 4.76 \\
\hline Total & $\mathbf{1 0 5}$ & $\mathbf{1 0 0}$ \\
\hline
\end{tabular}

Source: U.S. Department of the Interior (DOI) 
Data from the only known comprehensive report published by DoD (1999) on the number of HBCU graduates who have been commissioned from the ROTC programs by the U.S. military, show that in 1996, of the 10 percent or 706 of the total number of ROTC commissions awarded to African Americans, 43 percent were conferred to HBCU graduates. As aforementioned, the Army is the largest beneficiary of these graduates with 20 ROTC programs at HBCUs or 46 percent of the total number of Black officers commissioned in the Army through ROTC programs (DoD 1999). The remaining branches of the military - Air Force, Navy and Marine Corps - garner 30 percent, 53 percent and 42 percent of the total number of HBCU graduates. Table 2 shows the distribution of HBCU graduates who have been commissioned by the U.S. military from ROTC programs for 1996.

Table 2. Graduates Who Have Been Commissioned in the U.S. Military from ROTC Programs by Race for 1996

\begin{tabular}{|c|c|c|c|}
\hline Race & Total & HBCU & Percent \\
\hline Army & & & \\
\hline All races & 4,256 & 254 & 6 \\
\hline Black & 479 & 220 & 46 \\
\hline Navy & & & 5 \\
\hline All races & 852 & 43 & 53 \\
\hline Black & 62 & 33 & \\
\hline Marines Corps & & & 42 \\
\hline All races & 200 & 6 & 4 \\
\hline Black & 12 & 5 & 30 \\
\hline Air Force & & & \\
\hline All races & 1,759 & 67 & 5 \\
\hline Black & 153 & 46 & \\
\hline $\begin{array}{c}\text { All military } \\
\text { branches }\end{array}$ & & & \\
\hline All races & 7,067 & 370 & \\
\hline Black & 706 & 304 & \\
\hline
\end{tabular}

Source: U.S. Department of Defense, Career Progression of Military and Women Officers 1999. 


\section{What is the Role of HPO Initiatives at HBCUs?}

Studies on how African Americans perceive the value of physical education and/or exercise programs tend to emphasize the role of student socioeconomic status (i.e., Jacob 1992) as well as race (DeSensi 1992). Quartermann et al. (1996) refuted these findings however by showing that African American students at HBCUs did not differ from White students in how they valued physical education. In fact, the African American students surveyed in the study valued such statements as "Keeping in good health and physical conditioning," "achieving success," "improving self-confidence," and "getting regular exercise" as the most important of 24 statements presented (Quartermann et al. 1996, p.196). Most importantly, students valued self-efficacy. Therefore, it is recommended that physical and exercise education instructors create or develop techniques that foster, nurture, and sustain the self-confidence and self-worth of African American students and in turn utilize such data to make decisions about what areas in their courses to emphasize. According to Quartermann et al. (1996), African American students perceive physical education or exercise courses as opportunities for increasing self-worth and self-esteem. Their study concluded that race may not be important in determining whether or not African American students participate in physical education or exercise programs.

It is surmised that given DoD's broad umbrella and resultant definition of human performance optimization, the military could benefit from HPO-like academic offerings at HBCUs, especially since HBCUs with ROTC programs have continued to prove their worth by producing the best and brightest African American officers to the services. HBCUs, beyond those with ROTC programs, could provide an invaluable resource for the military to learn and enhance its own HPO initiatives by adapting like or complementary elements of HBCUs' performance driven academic programs. The prospective and innumerable benefits to be derived from accommodating this approach would have wide reaching effects for the military, not the least of which would function to reinforce the symbiotic relationship between the parties and expand the scope of these partnerships, 
to include attracting other HBCUs not currently in partnership with the military.

\section{Minority Recruitment and HPO Endeavors within the International Community}

The U.S. military is not unique in its experience in becoming increasingly reliant on a minority workforce. Militaries around the world are contending with this issue. Winslow et al. (2006) believes that this change was inevitable given the move to all volunteer forces. Additionally, some militaries have installed equal opportunity goals in keeping with the legislations enacted for their civilian sectors. Here, the definition of what constitutes a minority ${ }^{3}$ varies with each country. For example, Canada fashioned its recruitment of minorities (i.e., women, Aboriginals and visible minorities) after its Employment Equity Act (Rueben 2004). Yet, despite this move, the Canadian military struggles to increase its minority representation even though approximately 80 percent of the country's minorities are employed in the civilian sector (Winslow et al. 2006, Canadian Department of National Defense 1999) and 18.4 percent of its civilian population is comprised of minorities (Rueben 2004). This lackluster recruitment of minorities is also evident in the Australian military (Silk et al. 2000). Recruitment by Britain's Royal Air Force, Marines and Navy have resulted in modest increases in women (Dandeker and Winslow 1999) although less success has been expected with minorities where only one percent comprise the military versus six percent in the civilian population.

The Netherlands has been even less successful in its minority recruitment (Bosman et al. 2007). Although the country strives for the military to reflect the diversity of its civilian population, and in light of an inordinately high unemployment rate among minorities (i.e., Turks), attitudes towards the Dutch movement to multiculturalism are uniformly negative. For countries in Western Europe - like Germany - the declining population compounded by low fertility rates and shifting demographics, may force the Bundeswehr to recruit minorities (i.e., Turks) as one way of increasing its military force (Winslow et al. 2006). However, doing so may include having to apply less stringent naturalization rules for minorities to be recruited. Lastly, South Africa has grappled with applying post-apartheid policies and newly enacted laws requiring the integration of two divergent forces and former enemies - 
the White South African Defense Force (SADF) and the Black African National Congress (ANC) (Bosman et al. 2007). The new laws were established to create the South African National Defence Force (SANDF) amid multiple tensions. Like the United States, legislation called for affirmative action as a remedy for employment inequities - the SANDF turned to the U.S. military's Defense Equal Opportunity Management Institute (DEOMI) for training on equal opportunity.

Whereas the minority recruitment challenges of international militaries are well known, the degree to which they are engaged in human performance optimization is burgeoning. A number of member nations that comprise the North Atlantic Treaty Organisation (NATO), including the United States, are actively pursuing HPO activities at some level. More recently, a compendium of papers, representing a wide range of these activities, entitled Human Performance Enhancement for NATO Military Operations (Science, Technology and Ethics), was prepared and presented at a NATO symposium (Research and Technology (RTO) Meeting Proceedings 2009). The topics ranged from considering the ethical limitations of improving soldiers' physical performance (Bigard et al. 2009) to the role of alcohol use on military performance (Meijer and Verral 2009). First, the French Army considered the ethics of trying to improve the physical performance of athletes (or non-military members) through such techniques as using drugs and gene doping (Bigard et al. 2009). Second, by all indications, the Dutch appears to be the most active in their pursuit of HPO efforts. For instance, surveys of the Dutch military in 2006 and 2008, respectively, were used to document alcohol use and then developed strategies to reduce consumption (Meijer and Verrall 2009). Although personnel in the Air Force use less alcohol than those in the Army, alcohol use has been shown to increase precipitously prior to troop deployments as such use is prohibited in the theater of operations. Alcohol use can adversely impact military performance by increasing the risk of injury and mistakes by troops as well as decrements in performance. The Dutch are also examining other ways to enhance performance to include exercise intensity and energy expenditure in military training (Westerterp et al. 2009), the brain (Van Erp et al. 2009) and cognitive (Veenstra et al. 2009) performance enhancement effects of psychoactive pharmaceuticals on military performance (Meijer and DeVries 2009), the role of personal intuition on pilot performance (Groen et al. 2009) 
and monitoring the performance of military personnel under extreme conditions such as those found in Afghanistan (Valk and Veenstra 2009).

Third, the Canadians are experimenting with intelligence adaptive interface (IAI), a tool designed for improving the human-machine interface and thus an operator's performance and control over military equipment like the uninhabited aerial vehicle (UAV) in urban operations (Hou and Zhu 2009). The Germans, in coordination with the Dutch, envision the use of science fiction as a template for neural and biological enhancements for soldiers (Reschke et al. 2009). This could help gain asymmetric advantage on the battlefield. Finally, the British military, together with the U.S. military, determined that Mission Training through Distributed Simulation (MTDS) and the application of Mission Essential Competency (MEC), benefitted warfighters' participation and improved their shared situational awareness for optimizing the missions (Dudfield 2009). Overall, the research to date reflects a pattern that HPO initiatives beyond those of the U.S. military and among NATO countries are independent and collaborative in nature.

\section{Methodology and Results}

An exhaustive search of the Internet was conducted to determine if and the degree to which HBCUs with HPO-like academic offerings exist to potentially complement U.S. military HPO initiatives. Ninety one institutions were identified among the 105 HBCUs listed by the U.S. Department of Education (DOE) (U.S. DOE website). Among these institutions, 72.3 percent $(\mathrm{N}=76)$ were affiliated with ROTC programs already housed in or linked to affiliated institutions (goROTC website, College Profiles website). However, because some of the pertinent information was missing from some websites that were reviewed, one additional step was taken to garner the information by directly contacting those HBCUs with ROTC programs via telephone.

For the most part, HPO initiatives in the U.S. military use physical performance outcomes to successfully meet the mission. Two important aspects of this performance are physical fitness and nutrition. Expertise in these areas is paramount to housing interdisciplinary programs surrounding HPO initiatives at HBCUs. For this purpose, programs at HBCUs with these foci were included as part of the search for HPO like academic offerings. 
Therefore, HPO-like academic offerings within HBCUs consisted of health and nutrition related programs with advanced degrees and/or those programs that partner with PWI institutions with graduate courses in their respective fields. Table 3 below provides a list of HPO-like academic offerings at HBCUs (HBCUs with Advanced Degree Programs, Directory of HBCU Programs for Nontraditional Students, Directory of HBCU Distance Learning Programs, HBCU Combined Degree and Exchange Programs, U.S. Department of the Interior (DOI)). Of the 91 HBCUs, only 41 offer advanced degrees of which 26 are HPO related, 19 of which are HPO-like academic offerings and the remaining institutions or 7 in partnerships with PWIs. Upon review of the 41 HBCUs with advanced degrees, 16 listed academic programs under the categories of physical and/or recreational education, sports science and health education (HBCUs with Advanced Degree Programs) while another four were identified under nutritional science. Two institutions with distance learning programs offered the academic specialties of health and fitness and occupational safety and health (Directory of HBCU Distance Learning Programs) while another five HBCUs with programs for nontraditional students, framed these programs under other categories, i.e., kinesiology, healthcare and fitness, physical education and health sciences (Directory of HBCUs for Nontraditional Students). Although it is difficult to ascertain what other programs might promote HPO-like education, a few HBCUs offered interdisciplinary studies which may be interpreted to mean an array of courses subsumed under this category. Some HBCUs offered more than one type of HPO-like academic offering.

As stated, seven (7) HBCU programs were identified as featuring combined degree and exchange programs with predominantly White institutions (PWIs). Partnerships in medicine, dentistry, allied health, pharmacy, medical technology, physical therapy and nursing (HBCU Combined Degree and Exchange Programs) were found, but only those programs deemed within the realm of military HPO initiatives - pharmacy and allied health programs - are included. In total, 19 of the 27 HBCUs with ROTC programs have been identified as having some type of academic offerings that may be classified as reflecting the parameters of HPO like programs similar to those of the U.S. military. In addition, most of these HBCUs are public institutions that receive some level of funding from the federal government. The remaining HBCUs with HPO like academic offerings are privately held institutions. It 
is interesting to note that all but two of the HBCUs highlighted presently have established ROTC programs with the U.S. military. There appears to be

\section{Table 3. HBCUs with Human Performance Optimization Like Academic Offerings}

\begin{tabular}{|c|c|c|c|c|c|c|}
\hline & Institution & Location & Program & $\begin{array}{l}\text { Level of } \\
\text { Program }\end{array}$ & $\begin{array}{l}\text { Combined } \\
\text { Degree \& } \\
\text { Exchange }\end{array}$ & ROTC \\
\hline 1 & $\begin{array}{c}\text { Alabama A \& M } \\
\text { University }\end{array}$ & Normal, AL & $\begin{array}{c}\text { Health \& Physical Education } \\
\text { Food Nutrition }\end{array}$ & $\begin{array}{c}\text { M } \\
\text { Other }\end{array}$ & No & Yes \\
\hline 2 & $\begin{array}{l}\text { Alabama State } \\
\text { University }\end{array}$ & Montgomery, AL & Physical Education & $\mathrm{M}, \mathrm{O}$ & No & Yes \\
\hline 3 & $\begin{array}{l}\text { Albany State } \\
\text { College }\end{array}$ & Albany, GA & Health \& Physical Education & M & No & No \\
\hline 4 & $\begin{array}{l}\text { Florida A \& M } \\
\text { University }\end{array}$ & Tallahassee, FL & $\begin{array}{l}\text { Pharmacology/Toxicology } \\
\text { Pharmaceutical Science }\end{array}$ & $\begin{array}{l}\mathrm{M} \\
\mathrm{D}\end{array}$ & & Yes \\
\hline 5 & $\begin{array}{l}\text { Grambling State } \\
\text { University }\end{array}$ & Grambling, LA & Sports Administration & M & & Yes \\
\hline 6 & $\begin{array}{l}\text { Howard } \\
\text { University }\end{array}$ & Washington, D.C. & $\begin{array}{c}\text { Physical Education and } \\
\text { Recreation } \\
\text { Physiology and Biophysics }\end{array}$ & $\begin{array}{l}\mathrm{M} \\
\mathrm{D}\end{array}$ & $\begin{array}{l}\text { Yes, programs } \\
\text { unknown }\end{array}$ & Yes \\
\hline 7 & $\begin{array}{l}\text { Jackson State } \\
\text { University }\end{array}$ & Jackson, MS & $\begin{array}{l}\text { Health, Physical Education \& } \\
\text { Recreation }\end{array}$ & M & & Yes \\
\hline 8 & $\begin{array}{l}\text { Meharry Medical } \\
\text { College }\end{array}$ & Nashville, TN & $\begin{array}{c}\text { Biomedical Sciences } \\
\text { (Pharmacology \& } \\
\text { Physiology) } \\
\text { Physical Therapy } \\
\text { Occupational Therapy }\end{array}$ & $\begin{array}{l}\text { M.D } \\
\text { M } \\
\text { B }\end{array}$ & & Yes \\
\hline 9 & $\begin{array}{l}\text { Morgan State } \\
\text { University }\end{array}$ & Baltimore, MD & $\begin{array}{c}\text { Physical Education } \\
\text { Recreation Administration \& } \\
\text { Supervision }\end{array}$ & $\begin{array}{l}\mathrm{M} \\
\mathrm{M}\end{array}$ & Pharmacy & Yes \\
\hline $\begin{array}{l}1 \\
0\end{array}$ & $\begin{array}{l}\text { Morehouse } \\
\text { School of } \\
\text { Medicine }\end{array}$ & Atlanta, GA & Medicine & $\mathrm{D}$ & & No \\
\hline $\begin{array}{l}1 \\
1\end{array}$ & $\begin{array}{l}\text { North Carolina A } \\
\text { \& T State } \\
\text { University }\end{array}$ & Greensboro, NC & $\begin{array}{l}\text { Health \& Physical Education } \\
\text { Food \& Nutrition }\end{array}$ & $\begin{array}{l}\text { M } \\
M\end{array}$ & & Yes \\
\hline $\begin{array}{l}1 \\
2\end{array}$ & $\begin{array}{l}\text { North Carolina } \\
\text { Central University }\end{array}$ & Durham, NC & $\begin{array}{c}\text { Physical \& Recreation } \\
\text { Management } \\
\text { Physical Education }\end{array}$ & $\begin{array}{l}\text { M } \\
M\end{array}$ & & Yes \\
\hline $\begin{array}{l}1 \\
3\end{array}$ & $\begin{array}{l}\text { Prairie View } \\
\text { A\&M }\end{array}$ & Prairie View, TX & Health \& Physical Education & M & & Yes \\
\hline $\begin{array}{l}1 \\
4\end{array}$ & $\begin{array}{l}\text { South Carolina } \\
\text { State University }\end{array}$ & Orangeburg, SC & Nutritional Science & M & & Yes \\
\hline $\begin{array}{l}1 \\
5\end{array}$ & $\begin{array}{l}\text { Southern } \\
\text { University and A } \\
\text { \& M College }\end{array}$ & Baton Rouge, LA & Therapeutic Recreation & M & & Yes \\
\hline $\begin{array}{l}1 \\
6\end{array}$ & $\begin{array}{l}\text { Tennessee State } \\
\text { University }\end{array}$ & Nashville, TN & $\begin{array}{l}\text { Health \& Physical Education } \\
\text { (Recreation \& } \\
\text { Administration) }\end{array}$ & M & & Yes \\
\hline
\end{tabular}




\begin{tabular}{|c|c|c|c|c|c|c|}
\hline & Institution & Location & Program & $\begin{array}{l}\text { Level of } \\
\text { Program }\end{array}$ & $\begin{array}{l}\text { Combined } \\
\text { Degree \& } \\
\text { Exchange }\end{array}$ & ROTC \\
\hline $\begin{array}{l}1 \\
7\end{array}$ & $\begin{array}{l}\text { Texas Southern } \\
\text { University }\end{array}$ & Houston, TX & $\begin{array}{c}\text { Health Education } \\
\text { Physical Education } \\
\text { Aerobic Dance } \\
\text { Jazz }\end{array}$ & $\begin{array}{c}\text { M } \\
\text { M } \\
\text { Nontraditional } \\
\text { Nontraditional }\end{array}$ & & Yes \\
\hline $\begin{array}{l}1 \\
8\end{array}$ & $\begin{array}{c}\text { Tuskegee } \\
\text { University }\end{array}$ & Tuskegee, AL & Food \& Nutritional Science & M & & Yes \\
\hline $\begin{array}{l}1 \\
9\end{array}$ & $\begin{array}{l}\text { University of } \\
\text { Maryland Eastern } \\
\text { Shore }\end{array}$ & $\begin{array}{c}\text { Princess Anne, } \\
\text { MD }\end{array}$ & $\begin{array}{c}\text { Toxicology } \\
\text { Physical Therapy }\end{array}$ & $\begin{array}{c}\text { M.D } \\
\text { M }\end{array}$ & & No \\
\hline $\begin{array}{l}2 \\
0\end{array}$ & $\begin{array}{l}\text { Houston-Tillotson } \\
\text { University }\end{array}$ & Austin, TX & Kinesiology & Nontraditional & & Yes \\
\hline $\begin{array}{l}2 \\
1\end{array}$ & $\begin{array}{c}\text { Lincoln } \\
\text { University }\end{array}$ & Philadelphia, PA & Healthcare \& Fitness & $\begin{array}{l}\text { Nontraditional } \\
\text { Distance } \\
\text { Learning }\end{array}$ & & Yes \\
\hline $\begin{array}{l}2 \\
2\end{array}$ & $\begin{array}{l}\text { St. Phillip's } \\
\text { College }\end{array}$ & San Antonio, TX & Health Sciences & Nontraditional & & Yes \\
\hline $\begin{array}{l}2 \\
3\end{array}$ & $\begin{array}{c}\text { Norfolk State } \\
\text { University }\end{array}$ & Norfolk, VA & $\begin{array}{c}\text { Occupational, Safety \& } \\
\text { Health }\end{array}$ & $\begin{array}{l}\text { Distance } \\
\text { Learning }\end{array}$ & & Yes \\
\hline $\begin{array}{l}2 \\
4\end{array}$ & Spelman College & Atlanta, GA & & & Pre med & Yes \\
\hline $\begin{array}{l}2 \\
5\end{array}$ & Fisk University & Nashville, TN & & & Pharmacy & Yes \\
\hline $\begin{array}{l}2 \\
6\end{array}$ & Dillard University & New Orelans, LA & & & Allied Health & Yes \\
\hline
\end{tabular}

Source: HBCUs with Advanced Degree Programs, Directory of HBCU Programs for Nontraditional Students, Directory of HBCU Distance Learning Programs, HBCU Combined Degree and Exchange Programs, U.S. Department of the Interior (DOI), U.S. Department of Education, goROTC.com, CollegeProfiles.com

some relationship between the presence of ROTC programs and the presence of HPO-like academic offerings at HBCUs.

Given the above, the authors speculate that the seeming dearth of physical education, sports science, and/or other sports-like programs at many HBCUs may not be surprising. The emphasis may have been placed on more academic programs as a way of leveling the playing field for African American students rather than highlighting programs that emphasize physical or sports education. The institutions recognize that once their students graduate, they will be forced to contend with the ills of racism, even in modern American society. Further, the stereotypes of African Americans as athletes, particularly African American males, are well known. Entine (2000) points to the "dumb jock" (p.337) appendage that has been used to describe all athletes, but especially African American athletes, and Leonard (1998) speaks of the belief by Americans of the innate athletic ability of African 
American males who are otherwise intellectually compromised. Certainly the disproportionate presence of African American male athletes in Division 1 or revenue generating athletic programs at PWIs (National Collegiate Athletic Association (NCAA) 2002, 2009) highlights the focus of the athleticism of Black males who continue to represent the largess of football and basketball players. For the 1999 to 2000 through 2007 to 2008 periods, Black athletes' representation increased from 42 percent to 47.5 percent of football players and 57 percent to 60.4 percent of basketball players. Regrettably, African American males comprise only 11 percent of enrollments at colleges and universities.

Accordingly, this treadmill oblivion of the systematic mistreatment of Black athletes (Edwards 1984) or the conveyor belt, as it is sometimes called (Rhoden 2006), to connote the assembly line production of these athletes, may help to explain the absence of HPO-like academic programs at HBCUs. In a study by Steinfeldt et al. (2009), African American athletes at HBCUs were less likely than those at PWIs to identify themselves as athletes and African American football players at HBCUs were more likely than those at PWIs to describe themselves as Black more strongly than as athletes. Although it is only conjecture by the authors, many HBCUs might have deliberately moved to underscore the criticality of academics over physical and/or athletic prowess in their curricula, perhaps to consciously diffuse these powerful and persistent foci on African American males as athletes.

The data from this present study then suggest that a limited number of HBCUs offer advanced degrees in some academic fields, with less than half of them offering advanced degrees in HPO related fields. This could also speak to the innumerable challenges that HBCUs face in funding to sustain these academic offerings, recruit faculty, and perhaps a lack of interest in offering such programs. However, it is beyond the scope of this paper to suggest why more advanced degrees are not being offered at more HBCUs. What the data does suggest though is that there is some level of HPO-like activity at HBCUs and on which the U.S. military can capitalize. The U.S. military can therefore leverage its long standing relationship with those HBCUs with ROTC programs to engage these and other HBCUs in future HPO initiatives. 


\section{The Importance of HPO-Like Academic Offerings at HBCUs for the U.S. Military}

It goes without saying that African American men and women are critical to the U.S. military and HBCUs have been an integral part of that journey. However, among the multiple challenges they must confront, African Americans as a group suffer disproportionately from health and healthcare disparities, even when access to healthcare and healthcare insurance are available and on par with that of Whites (Institute of Medicine (IOM) 1999, 2001, 2003; Steel Fisher 2004; Betancourt et al. 2005). Another recent analysis shows that if not proactive, the military could also become susceptible to the compromised health and healthcare disparities of newly recruited groups, including African Americans (Harris forthcoming). This would evolve as a consequence of the compromised baseline health status of those coming from the civilian population. The military and HBCUs could markedly benefit from forging a mutual alliance in an attempt to eradicate health and healthcare disparities among African Americans. Specifically for the military, knowledge of this potential encroachment of health and healthcare disparities of African Americans can augment the institution's own knowledge to better prepare for capability and performance challenges of African American warfighters in both the commissioned and enlisted corps. In doing so, the military not only arms itself with preventive measures, but can employ such data garnered from HBCUs about HPO-like academic offerings in helping to address any anomalies that hinder the capability and performance of the African American warfighter. The military also stands to benefit from modeling elements of HPO-like academic offerings and the expanded alliance with HBCUs in a number of other very important ways, notwithstanding the mutual benefits that can be derived.

\section{A. Source of Recruitment}

The presence of former high ranking U.S. military officers at the deliberation of the University of Michigan's landmark cases of Gratz v. Bolinger et al. (2003) and Grutter v. Bollinger et al. (2003) before the U.S. Supreme Court, signaled the importance of affirmative action programs and by extension the consideration of race and/or ethnicity in the selection of officers for the 
military (Karabel 2003). According to these former military officers, race is of a "compelling government interest" and is vital to national security (Karabel 2003, p.2). Additionally, race and/or ethnicity have been found to be important predictors of recruiting patterns in the military (Bachman et al. 2000, Segal and Wechsler Segal 2004). For the enlisted corps, the military targets "high quality recruits" or those who aspire to attend college and thus are more likely to complete their terms of enlistment (Bachman et al. 2000, p.4). However, recruitment for African Americans between the ages of 18 through 24 has suffered a steady decline over the years (Baldor 2007, Regan 2005). African Americans are deferring the decision to join the military to the counsel of their elders (i.e., teachers, pastors, coaches) (White 2005). Because of the role that HBCUs serve in African American life, these institutions can become vital centers for helping the military to recruit more African Americans. Further, the majority of HBCUs are concentrated in the South (Armstrong 2002), a region where sentiments about the military are the most favorable and may function in some way to facilitate recruitment for the military.

While HBCUs continue to be a major source of recruitment of Black officers for the military, the military experiences gnawing problems with the recruitment and retention of African Americans, and for the purpose of this paper, African American officers, in certain occupations. For example, although Blacks comprise the largest racial and/or ethnic group within the enlisted corps across all of the services (Segal and Wechsler Segal 2004, Population Report 2008), with the exception of the Army, they are underrepresented within the commissioned corps (Population Report 2008). Likewise, Black officers disproportionately fail to advance at the midpoint of their careers or the move from senior company grade (0-3) to the first field grade (0-4) level (Hosek et al. 2001, DoD 1999). Black officers, especially Black female officers, are the least likely of any demographic to be promoted (Hosek et al. 2001). But once promoted, Black officers are far more likely than their White peers to remain in the military until the next promotion cycle (Hosek et. al. 2001).

Nevertheless, what contributes to the disproportionate failure of African American officers is that, unlike their White peers, they are far more likely to be concentrated in the support occupations (i.e., supply, medical, 
administrative) (Segal and Wechsler Segal 2004) and, consequently, are less likely to be found in the technical career fields (i.e., aviation, special operations, combat arms) (Hosek et al. 2001, Harrel et al. 1999, DoD 1999, Burke 2001) from which the military leadership is drawn. For this reason, there is a corresponding underrepresentation of Black leadership in the military (Reyes 2008, Dyer 2010, Butler 1999). Even the overrepresentation of Black officers in the Army still translates into an anemic supply of Black officers within the senior ranks to serve as mentors for Black officers at the junior level (Reyes 2008, Dyer 2010, Butler 1999). The military can then capitalize on the opportunity to not only increase the recruitment of Black officers, but also address the disproportionate shortage of Black officers in certain occupations and their lackluster promotion rates through expanded relationships with HBCUs. HBCUs can better prepare their students for technical careers by promoting them as well as strengthening academic program content.

\section{B. A Vehicle for Cultural Competence}

DeSensi (1994) sees cultural diversity as influential in distinguishing dissimilarities between groups. And given the prevailing health and healthcare disparities among African Americans and the potential similar ill effects for the military (Harris forthcoming), it will become just as important for the military to take the nuances of culture into consideration in the design of its HPO initiatives. One approach for helping to close the gap in these disparities between Whites, for instance, and the rates of African American warfighters, is through cultural competence. Like the general civilian population, despite the presence of health insurance and equal access to healthcare for some, African Americans in the military still experience disproportionate levels of disease burden and carry these patterns even with equal access to healthcare. Surveys by the Defense Equal Opportunity Management Institute (DEOMI) and others (i.e., Joseph 1997, Kennedy et al. 2007, Truhon 2007) showed how military personnel from different groups view its environment and how, given these perceptions, unintentional and/or intentional differences in healthcare delivery can occur. The military can use this information to incorporate cultural competence as a critical component of training for the African American warfighter. The institution routinely conducts surveys as a way of monitoring its cultural climate (DEOMI). 
Awareness and understanding of these sensibilities can go a long way in tailoring HPO initiatives to maximize the capability and performance of the African American warfighter. The military can also leverage its in house expertise at DEOMI in designing culturally competent training for cultural readiness.

\section{Family Orientation}

One reason why HBCUs show intellectual promise for the grooming of Black leadership is the often mentioned reputation of the institutions for fostering a sense of belonging (Brown 2004, Steinfeldt et al. 2009, Collins and Homaifar 2007). HBCUs provide nurturing environments and instill racial pride (Brown 2004). The campuses exude a family atmosphere not found at PWIs (Steinfeldt et al. 2009) and cultivate the development of close faculty student relationships (Steinfeldt et al. 2009, Collins and Homaifar 2007) which is facilitated by small class sizes that may even extend to the personal involvement of faculty when deemed necessary (Collins and Homaifar 2007). When Black troops suffered the indignation of racial attacks, it was DoD that first established policies and the Defense Race Relations Institute in 1963 and 1971, respectively, to deter biases and attacks against its troops (DEOMI, Evans 2003). Because the military's environment is also communal, reinforced by the ethos of esprit de corps, it can capitalize on its past achievements in protecting African Americans by modeling segments of HPO-like academic offerings from HBCUs as a way of promoting itself as taking care of its own.

\section{Responding to Changing Demographic Needs}

The challenges presented by health and healthcare disparities among African Americans in the general civilian population and, correspondingly, the chances for potential similar effects in the military (Harris forthcoming) create an opportunity for the military to respond to the needs of this demographic shift in its population. In modeling aspects of HPO-like academic offerings from those of HBCUs and in keeping with force health protection and the Military Health System (MHS), the military is forced to reckon with multiple factors that, despite the presence of its equal access healthcare system, may unintentionally contribute to inequities in the healthcare it administers. These known factors are attributed to the patient, 
the provider and the system (IoM 2003, Berwick 2002, National Healthcare Disparities Report (NDHR) 2010).

At the patient level, for instance, cultural norms persist in how African Americans perceive the healthcare that is being rendered and/or their cultural beliefs about healthcare are advanced by the distrust of healthcare providers, the healthcare system and specifically the federal government (U.S. General Accountability Office (GAO) 2003, IoM 2003). It is no secret that in light of the historical treatment of African Americans by the federal government in general, the depth of distrust that still exists on the part of the Black community should not be dismissed, especially with regard to healthcare (i.e., Tuskegee experiment) (Graham 2007). Provider and system level factors, on which the IOM (2003) squarely placed the preponderance of the blame for these inequities, stem from multiple arenas. This includes disrespectful healthcare delivery as perceived by the patient that extends from the provider's failure to engage the patient as part of the decision making process (Johnson et al. 2004), blatant provider bias against the patient (Burgess et al 2004, Street et al. 2007) and the practice of "cognitive shortcuts" (IOM 2003, p.11) to prevent bottlenecks in the system. Knowledge of these factors helps to heighten the awareness of the military to be mindful of how healthcare is being delivered, what elements of HPO-like academic offerings can be adapted from HBCUs to mitigate these effects and how training can be designed to optimize the capability and performance of African American warfighters. These strategies can be mutually beneficial to HBCUs in that knowledge gained from military HPO initiatives can be used to improve health and wellness or human performance based programs at HBCUs to educate students and the larger Black communities in which they are geographically located. Equally important, particularly for HBCUs with ROTC programs, is that these strategies for collaboration can empower HBCU students by introducing them to the importance of HPO initiatives for personal and professional growth and physical and psychological resilience as early as possible.

\section{E. Increased Readiness}

The need for HPO initiatives originated from the goal to increase mission readiness. A number of joint initiatives have been created as part of the larger effort of optimizing the performance of the warfighter. One such 
initiative is the Consortium for Health and Military Performance (CHAMP). CHAMP is an alliance of clinicians, educators and researchers who are dedicated to exploring and identifying those human factors that contribute to and maximize the human performance of the warfighter by enlisting the partnership of the research, medical and operational communities. Housed in the Uniformed Services University of the Health Sciences (USUHS), CHAMP's mission is to bring about the optimization of warfighter performance through research, education and expertise by engaging such diverse stakeholders as DoD and its respective commands; military treatment facilities (MTF); researchers; policy makers; and the warfighter. This consortium can be expanded to give voice to HBCUs via participation in such dialogues. Figure 1 below offers a conceptual framework of the prospect for collaborations on HPO initiatives between the U.S. military and HBCUs. With the warfighter at the center of these expanded collaborations, the objectives for the military are for increased preparedness, sustained and increased readiness and optimized performance.

Figure 1: HPO Initiatives: A Conceptual Framework for
Prospective Relations between the Military and HBCUs

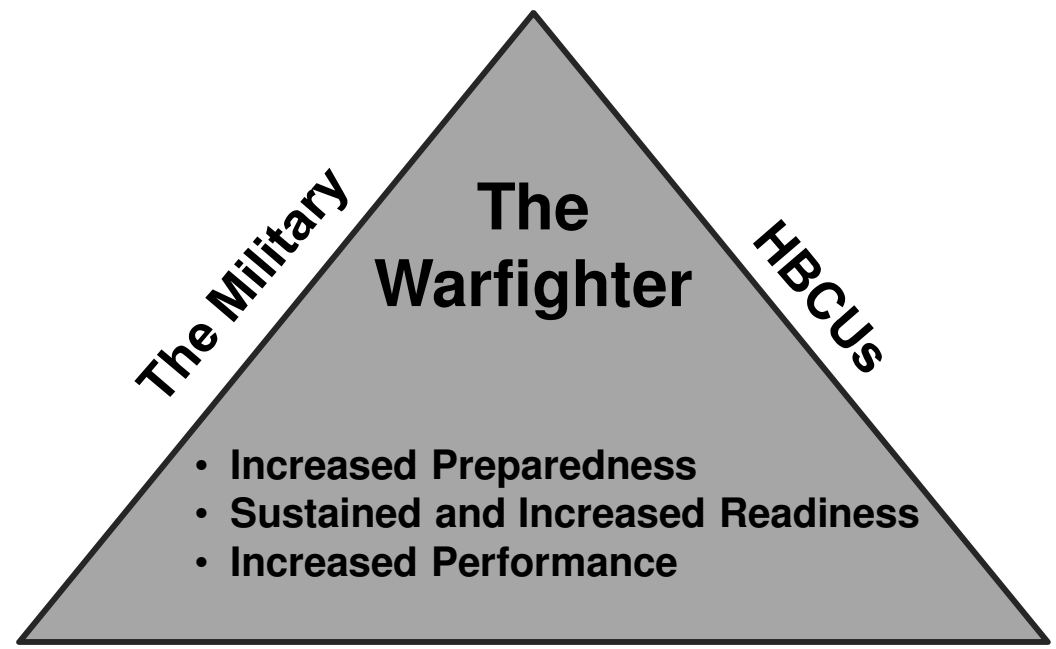

HPO Initiatives 


\section{Conclusion}

The ever changing national security landscape of the United States, compounded by an equally dynamic battlefield, has moved the U.S. Department of Defense and, in turn, the U.S. military, to place renewed focus on the warfighter. The U.S. military's goal is to preemptively respond to evolving threats and explore measures for securing asymmetric advantage over its enemies by positioning the warfighter at the center of its weapons system. Through HPO initiatives, the military seeks to optimize the capability and performance of the warfighter for increased mission readiness. African American officers, by way of ROTC programs at HBCUs, must be an essential part of this strategy. However, it is believed that the scope and nature of the relationship between the military and HBCUs can be expanded with the military adapting key elements of HPO initiatives which are deemed to mirror or are similar to programs existing at HBCUs. These HPO-like academic offerings, as they are called, may take many forms, and should promote physical, psychological, and nutritional education and/or health and wellness programs. The military can employ these HPO-like academic offerings to more accurately address the unique and cultural training needs of the African American warfighter. Activity on the international level among NATO countries in the pursuance of HPO initiatives is also evident. These countries, like the United States, are struggling with the recruitment of minorities into their militaries although unlike the United States, the definition of what constitutes a minority is not only country specific but efforts with the recruitment of minorities is less coordinated and experienced.

It is believed that the U.S. military can use this opportunity to make additional and lasting inroads with HBCUs by modeling elements of HPOlike academic offerings within HBCUs. First, the continual decline in the recruitment, promotion and retention rates of Black officers in the military is disquieting. Especially important will be the development of long term military strategies for placing African American officers in technical career fields and grooming them for senior leadership positions. Second, the military can be more responsive to the unique circumstances of the African American warfighter by designing culturally competent training. Third, 
because the military is communal in nature and thrives on a culture of esprit de corps, it can capitalize on its history as a pioneer for instituting the first known equal employment policies and governing body to protect African American troops from unwarranted attacks. Fourth, the military can use the full force of what is available at its disposal (i.e., knowledge, expertise, research, networks and resources) in HPO initiatives and the Military Health System (MHS) to address the looming threat of health and healthcare disparities within the ranks of its African American force. In this regard, the military's expanded relationship can assist HBCUs in educating their own students and Black communities at large about this credible threat. Finally, by inviting HBCUs to collaborate with entities like CHAMP, and introducing them to HPO resources such as DoD's Human Performance Resource Center, the military can increase its network and work closely with HBCUs to share, establish and/or increase their participation in HPO initiatives. Doing so not only broadens the diversity of input for developing stronger HPO initiatives but also provides an avenue for helping the military to increase its level of cultural competence and readiness. The implications for these findings are the untapped and still yet to be discovered reservoirs of promise for HPO initiatives that lie ahead for prospective partnerships between the military and HBCUs.

\section{Implications for the Military}

The U.S. military stands to reap a multitude of benefits from modeling aspects of HPO-like academic offerings at HBCUs. Beyond those benefits already mentioned, the implications for this joint venture are far reaching. First, by enlisting the support of HBCUs, the diversity of views garnered for the improvement of military HPO initiatives can be broadened. Additionally, the depth and breadth of input from HBCUs will increase. Second, and particularly for those HBCUs with no formal relationships with the military such as the institution of ROTC programs, HPO-like academic offering projects can spur groups like HBCUs that otherwise would not have been consulted, to participate in and be part of the process. Third, this opportunity lends itself to the opening of further dialogue between the military and HBCUs. Fourth, further dialogue will potentially serve to solidify a sense of trust over time between the parties to dispel the myths about the federal government still harbored by many HBCUs and the larger 
Black community. Finally, relationships based upon mutual trust expand the horizon of opportunities for promoting expansion in the scope and nature of partnerships with HBCUs. In essence, alliances between the military and HBCUs on HPO initiatives, through cultural competence training and empowerment towards achieving optimal health, can lead to the increased preparedness of the warfighter, increased performance of the individual warfighter and military units, and sustained and increased readiness of the military.

NATO countries and other militaries around the world have already modeled at some level many of the equal opportunity training efforts of the United States, including receiving such training from the U. S. military's Defense Equal Opportunity Management Institute (DEOMI). They are also collaborating on HPO initiatives with the U.S. military. International militaries can expand these collaborations with the United States only by capitalizing on the strategies that have benefited the U.S. military with recruiting minorities, in this case African American officers, and by incorporating strategies for promoting HPO initiatives.

\section{Implications for HBCUs}

Like many academic institutions today, both public and private, the challenge of limited funding looms large for HBCUs. In an era of fiscal duress, federal, foundation and private funding have declined precipitously. HBCUs can take advantage of the vast networks and resources of the U.S. Department of Defense and the U.S. military to shore up shortfalls in their funding that could endanger infrastructure development. The depth and breadth of this knowledge, expertise, networks and research available to HBCUs are immeasurable, not to mention the potential benefits for recruiting talented faculty to these institutions.

\section{Implications for Future Research}

Future research on the role of HPO initiatives at HBCUs would benefit from further examination into the extent to which sports or athletics, physical education, exercise, health education and/or nutritional programs exist at HBCUs. It would be interesting to discern whether or not the absence of these programs at HBCUs can be attributed, as speculated by the authors, to the high visibility and sometimes unflattering reputation of Black athletes, 
particularly Black male athletes, at Division 1 predominantly White institutions. Moreover, of interest, is whether or not the existence of ROTC programs at HBCUs impacts the likelihood that these institutions will either have HPO-like academic offerings or more robust performance directed programs. Research can also be conducted on how militaries within the international community can continue to capitalize on those strategies that they have already modeled from the U.S. military as well as continuing to collaborate on existing and future HPO initiatives.

\section{NOTES}

1. The terms African American (s) and Black (s) are used synonymous and interchangeably.

2. HPO-like academic offerings are those non-military programs at HBCUs that are most similar in content and characteristics as military HPO initiatives.

3. For some countries, minorities also include women. The designation of minority may also be a condition of being an immigrant from another country or a descendant of immigrants or those regarded as non-natives who were born in the countries to which their fore parents emigrated.

\section{References}

Armstrong, B. 2002. A Virtual Assessment of Historically Black Colleges and Universities. Public Administration Program Applied Research Projects. Texas State University. http://ecommons.txstate.edu/arp/49. Retrieved July 21, 2010.

Bachman, J.G., Segal, D.R., Freedman-Doan, P. and O’Malley, P.M. 2000. Who Chooses Military Service? Correlates of Propensity and Enlistment in the U.S. Armed Forces. Military Psychology, 12, 1, 1-30.

Baldor, L.C. 2007. Decline for Military in Black Recruits. Associated Press, June 24.

Berwick, D.M. 2002. A User's Manual for the IoM's 'Quality Chasm' Report. Health Affairs, 21, 3, 60-87.

Betancourt, J.R., Green, A.R., Carillo, J.E., and Park, E.R. 2005. Cultural Competence and Health Care Disparities: Key Perspectives on Trends. Health Affairs, 24, 499-505.

Bigard, Xavier., Koulmann, Natalie., Banzet, Sebastien., Sanchez, Herve., and Malgoyre, Alexandra. 2009. Are There Ethical Limitations for Improving Physical Performance in Soldiers? The Research and Technology (RTO) Organisation Meeting Proceedings of NATO, 5-7 October. Sofia, Bulgaria.

Bosman, F., Richard, R., and Soeters, J. 2007. Multicultural Tensions in the Military? Evidence from the Netherlands Armed Forces. International Journal of International Relations, 31, 339-361.

Brown, Lex. 2010. Mil Docs Interview. July 15. 
Brown, J.M. 2004 (unpublished). Perceptions and Performance of African American Male Student-Athletes at a Historically Black University and a Predominantly White University.

Brown, L., and Tvaryanas, A.P. 2008. Human Performance Enhancement. Uberhumans or Ethical Morass? Air and Space Power Journal, Winter. December.

Burgess, D.J., Fu, S.S., and Van Ryan, M. 2004. Why Do Providers Contribute to Disparities and What Can Be Done About It? Journal of General Internal Medicine, 19, 1154-1159.

Burke, E.E. 2001. Black Officer Under-Representation in Combat Arms Branches. AY-01-02.U.S. Army Command and General Staff College.

Butler, R. 1999. Why Black Officers Fail? Parameters, Autumn, 54-69. U.S. Army War College.

Canadian Department of National Defence. 1999. Employment Equity Plan, Building Teamwork in Diverse Canadian Forces. Ottawa: Department of National Defence.

College Profiles. http://www.collegeprofiles.com. Retrieved April 3, 2011.

Collins, E.G., and Homaifar, A. 2007. HBCUs in Control. Control Programs at Historically Black Colleges and Universities. IEEE Control Systems Magazine, August, 106112.

Consortium on Health and Military Performance (CHMP). http://www.usuhs.mil/mem/chabout.html. Retrieved July 17, 2010.

Dandeker, C., and Mason, D. 1999. Diversity in the British Armed Forces: The Debate over Ethnic Minority Representation. Paper presented a conference on "Redefining Society -Military Relations: From Vancouver to Vladivostok," at the University of Birmingham, UK. April 16-18.

Defense Equal Opportunity Management Institute (DEOMI). http://www.deomi.org. Retrieved July 25, 2010.

DeSensi, J.T. 1994. Multiculturalism as an Issue in Sport Management. Journal of Sport Management, 8, 63-74.

Deuster, P.A., O’Connor, F.G., Henry, K.A., Martindale, V.E., Talbot, L., Jonas, W., and Friedl, K. 2007. Military Medicine, 172, 1133-1137.

Directory of HBCU Distance Learning Programs. http://www.dll.org/hbcus/Distance Learning/deafult.htm. Retrieved July 23, 2010.

Directory of HBCU Programs for Nontraditional Students. http://dll.org/hbcus/NonTraditionalStudents/default,htm. Retrieved July 23, 2010.

Dudfield, Helen. 2009. The Development of shared Mental Models during Air Battlespace Collective Training using Dispersed Networked Systems. The Research and Technology (RTO) Organisation Meeting Proceedings of NATO, 5-7 October. Sofia, Bulgaria.

Dyer, S. 2010. A Few Good Officers: HBCUs Seek Ways to Boost ROTC Pipeline. Black Issues in Higher Education.

Edwards, H. 1984. The Black “dumb jock": An American Sports Tragedy. The College Board Review, 131, 8-13.

Entine, J. 2000. Taboo: Why Black Athletes Dominate Sports and Why We're Afraid to Talk About It. New York: Public Affairs.

Evans, R. 2003. A History of the Service of Ethnic Minorities in the U.S. Armed Forces. Center for the Study of Sexual Minorities in the Military. University of California, Santa Barbara. June 26.

goROTC. http://www.goROTC.com. Retrieved April 3, 2011. 
Graham, G.N. 2007. Quality of Care and Health Disparities. In Eliminating Healthcare Disparities in America: Beyond the IoM Report. Humana Press, Inc. R.A. Williams, Editor.

Groen, Eric., Cornelisse, Erik-Jan., Jansen, Chris., van der Hoorn, John., and de Graaf, Bernd. 2009. Personalized Intuitive Displays Enhance Pilot Performance. The Research and Technology (RTO) Organisation Meeting Proceedings of NATO, 5-7 October. Sofia, Bulgaria.

Harrell, M.C., Nataraj Kirby, S., Sloan, J.S., Graf, C.M., McKelvey, C.J., and Sollinger, J.M. 1999. Barriers to Minority Participation in Special Operations Forces. RAND, Santa Monica, CA.

Harris, G.L.A. Forthcoming. Reducing Healthcare Disparities in the Military through Cultural Competence. Journal of Health and Human Services Administration.

HBCU Combined Degree and Exchange Programs. http://www.blackexcel.org/CD-

EP.htm.. Retrieved on July 23, 2010.

HBCUs with Advanced Degree Programs.

http://www.edonline.com/cq/hbcu/advdeg.htm. Retrieved on July 23, 2010.

Hosek, S.D., Tiemeyer, P., Kilburn, R., Strong, D.A., Ducksworth, S., and Ray, R.

Minority and Gender Differences in Officer Career Progression. RAND. Santa Monica, CA. Hou, Ming., and Zhu, Haibin. 2009. Intelligent Adaptive Interface: A Design Toll for Enhancing Human-Machine System Performances. The Research and Technology (RTO) Organisation Meeting Proceedings of NATO, 5-7 October. Sofia, Bulgaria.

Institute of Medicine (IoM). 1999. To Err is Human: Building a Safer Health System.

Washington, D.C. National Academies Press.

Institute of Medicine (IoM). 2003. Unequal Treatment. Confronting Racial and

Ethnic Disparities in Healthcare. Washington, D.C. National Academies Press.

Institute of Medicine (IoM). 2004. Monitoring Metabolic Status, Predicting

Decrements in Physiological and Cognitive Performance. Committee on Metabolic

Monitoring for Military Field Applications. National Academies Press..

Institute of Medicine (IoM). 2001. Crossing the Quality Chasm: A New Health

System for the Twenty-first Century. Washington, D.C. National Academies Press.

Jacob, J.E. 1992. The State of Black America. Vital Speeches of the Day, 57, 533-

537.

Johnson, R.L., Roter, D., Powe, N.R., and Cooper, L.A. 2004. Patient Race/Ethnicity and Quality Patient-Physician Communication During Medical Visits. American Journal of Public Health, 94, 12, 2084-2090.

Joseph, H.J. 1997. Attitudes of Army Nurses toward African American and Hispanic Patients. Military Medicine, 162, 96-100.

Karabel, J. 2003. Race and National Security.

http://csmonitor.com/2003/0328/p11S01-coop.html. Retrieved July 23, 2010.

Kennedy, C.H., Jones, D.E., and Arita, A.A. 2007. Multiculturalism Experiences of

U.S. Military Psychologists: Current Trends and Training Areas. Psychological Services, 4, 3, 158-167.

Leonard, W.M. 1998. A Sociological Perspective of Sport ( $5^{\text {th }}$ Edition). Allyn and Bacon. Needham Heights, MA.

Meijer, Marten., and Verrall, Neil. 2009. Alcohol Use and Military Performance. The Research and Technology (RTO) Organisation Meeting Proceedings of NATO, 5-7 October. Sofia, Bulgaria.

Meijer, Marten., and de Vries, Rodney. 2009. Psyho-Active Pharmaceuticals and

Military Performance in an Ethical Perspective. The Research and Technology (RTO)

Organisation Meeting Proceedings of NATO, 5-7 October. Sofia, Bulgaria. 
National Collegiate Athletic Association (NCAA). 2002. 2000-01 Student-Athlete Ethnicity Report. National Collegiate Athletic Association. Indianapolis, IN.

National Collegiate Athletic Association (NCAA). 2009. Student Athlete Ethnicity Report, 1999-2000 - 2007-2008. National Collegiate Athletic Association. Indianapolis, IN.

National Healthcare Disparities Report (NDHR) 2009. 2010. Agency for Healthcare

Research and Quality (AHQR). AHQR Publication No. 10-0004. U.S. Department of Health and Human Services. March http://www.ahrq.gov/qual/nhdr09/nhdr09.pdf.

Retrieved July 26, 2010.

North Atlantic Treaty Organisation (NATO). 2009. Human Performance

Enhancement for NATO Military Operations (Science, Technology and Ethics). The

Research and Technology Organisation (RTO) of NATO. RTO Meeting Proceedings. 5-7

October. Sofia, Bulgaria.

Office of the Under Secretary of Defense (OSD), Personnel and Readiness.1999.

Career Progression of Minority and Women Officers. Washington, D.C. Department of Defense.

Population Report (Representation in the Military Services). 2008.

http://prhome.defense.gov/MPP/ACCESSION POLIVY/PopRep2008/appendxb/b_29.html. Retrieved July 24, 2010.

Quartermann, J., Harris, G., and Chew, R.M. 1996. African American Students' Perceptions of the Values of Basic Physical Education Activity Programs at Historically Black Colleges and Universities. Journal of Teaching and Physical Education, 15, 188-203.

Rabbi, A.F., Ivanca, K., Putnam, A.V., Musa, A., Thaden, C.B., and Fazel-Rezai, R. 2009. Human Performance Evaluation based on EEG Signal Analysis: A Prospective Review. Conference Proceedings Annual International Conference, 1879-1892.

Reschke, Stefan., van Erp, Jan B.F., Brouver, Anne-Marie., and Grootjen, Marc. 2009. Neural and Biological Soldier Enhancement: From SciFi to Deployment. The Research and Technology (RTO) Organisation Meeting Proceedings of NATO, 5-7 October. Sofia, Bulgaria.

Reyes, A.D. 2008. Addressing the Challenge of Black Officer Underrepresentation in the Senior Ranks of the U.S. Army. Joint Center for Political and Economic Studies. July/August, 11-12.

Rhoden, W. 2006. Forty Million Dollar Slaves: The Rise, Fall, and the Redemption of the Black Athlete. New York. Crown.

Rueben, A.F. 2004. Recruiting Visible Minorities: A Matter of Survival. Canadian Force College. NSSC, 6, 1-59.

Sarewitz, D., and Karas, T.H. 2006. Report of the Workshop on the Policy Implications of Cognitive Enhancement Technologies. At Arizona State University, May 35 .

Segal, D.R., and Wechhsler Segal, M. 2004. America's Military Population. Population Bulletin, 59, 1, 1-42.

Silk, C.H.R., Boyle, R., Bright, A., Bassett, M., and Roach, N. 2000. The Case of Cultural Diversity in Defence. A report sponsored by the Defence Equity Organisation, Australian Defence Organisation. Prepared by the CRAWN project team as prt of the 2000 Senior Women in Management (SWIM) Program. October.

Singh, A., Bennett, T.L., and Deuster, P.A. 1999. Force Health Protection: Nutrition and Exercise Resource Manual. Department of Military and Emergency. F. Edward Hebert School of Medicine, Uniformed Services University of the Health Sciences (USUHS).

Steel Fisher, G.K. 2004. Addressing Unequal Treatment: Disparities in Healthcare. The Commonwealth Fund. Issue Brief. November, 1-9. 
Steinfeldt, C.R., and Steinfeldt, M.C. 2009. Racial and Athletic Identity of African American Football Players at Historically Black Colleges and Universities and Predominantly White Institutions. Journal of Black Psychology, 36, 1, 3-24.

Street, R.L., and Gordon, H. 2007. Physicians' Communication and Perceptions of Patients: Is it How They Look, How They Talk, or Is It Just the Doctor? Social Science and Medicine, 65, 586-598.

Truhon, S.A. 2007. Equal Opportunity in the Military: Are Differences in the Eye of the Beholder? Defense Equal Opportunity Management Institute (DEOMI).

http://www.deomi.org/EOEEEResources/ReportsStudies.cfm. Retrieved July 25, 2010.

Tvaryanas, A.P., Brown, L., and Miller, N.L. 2009. Managing the Human Weapon System. A -Vision for an Air Force Human-Performance Doctrine. Air and Space Power Journal, Summer. June.

U.S. Army Research Institute of Environmental Medicine.

http://www.usari.em.army.mill. Retrieved July 21, 2010.

U.S. Department of Education (DOE).

http://www2.ed.gov/about/inits/list/whhbcu/edlite-list-html.

U.S. Department of the Interior (DOI). Historically Black Colleges and Universities. HR Office of Educational Partnerships. http://www.doi.gov.gov/hrm/black.html. Retrieved on July 23, 2010.

U.S. General Accountability (GAO). 2003. Health Care: Approaches to Address Racial and Ethnic Disparities. GAO-03-862R. July 8.

Valk, Pierre J.L., and Veenstra, Bertil J. 2009. Military Performance and Health Monitoring in Extreme Environments. The Research and Technology (RTO) Organisation Meeting Proceedings of NATO, 5-7 October. Sofia, Bulgaria.

Van Erp, Jan B.F., Reschke, Stefan., Grootjen, Marc., and Brouver, Anne-Marie. 2009. Brain Performance Enhancement for Military Operators. The Research and Technology (RTO) Organisation Meeting Proceedings of NATO, 5-7 October. Sofia, Bulgaria.

Veenstra, Bertil., Visser, Taco., Rietjens, Gerard., Vrijkotte, susan., and Valk, Pierre. 2009. Ambulant Measurements of Physiological Status and Cognitive Performance during Sustained Operations. The Research and Technology (RTO) Organisation Meeting Proceedings of NATO, 5-7 October. Sofia, Bulgaria.

Westerterp, Klaas R., Rietjens, Gerard J.W.M., and Wouters Ing, Loek. 2009. Measurement of Exercise Intensity with a Trial-Axial Accelerometer during Military Training. The Research and Technology (RTO) Organisation Meeting Proceedings of NATO, 5-7 October. Sofia, Bulgaria.

White, J. 2005. Steady Drop in Black Army Recruits. The Washington Post, March 9.http://www.washingtonpost.com/wp-dyn/articles/A18461-2005Mar8.html Retrieved July $23,2010$.

Williams, E., Abarbanel, H., Brenner, M., Despain, A., Drell, S., Dyson, F., Joyce, G., Lewis, N., Press, W., and Vesecky, J. 2008. Human Performance. JSR-07-0625. JASON. The Mitre Corporation. http://handle.dtic.mil/100.2/ADA480029. Retrieved July 23, 2010.

Winslow, D.J., Heinecken, L., and Soeters, J.L. 2006. Diversity in the Armed Forces. In Handbook of the Sociology of the Miltiary. G. Caforio, Editor. Boston, MA. Springer Business Media, L.L.C. 